\title{
The Sedimentary record of Pleistocene aeolian - alluvial deposits on Vrgada Island (eastern Adriatic coast, Croatia)
}

\author{
Adriano Banak ${ }^{1 *}$, Kristina Pikelj², Borna Lužar - Oberiter ${ }^{2}$ and Branko Kordić ${ }^{1}$ \\ ${ }^{1}$ Croatian Geological Survey, Department for Geology, Sachsova 2, HR-10000 Zagreb, Croatia \\ (*corresponding author: abanak@hgi-cgs.hr tel.: +38516160 708; fax: +38516160 799) \\ 2 University of Zagreb, Faculty of Science, Department of Geology, Horvatovac 102, HR-10000 Zagreb, Croatia
}

doi: $10.4154 / g c .2021 .14$

\section{Article history:}

Manuscript received September 23, 2020 Revised manuscript accepted April 23, 2021 Available online June 30, 2021

\begin{abstract}
Vrgada Island is situated in the central part of the eastern Adriatic coast. Upper Cretaceous limestones crop out on the surface and Pleistocene sediments cover them in some parts of the island. This study focused on a coastal cliff trending $\mathrm{N}-\mathrm{S}$ on the northern part of the island. Aeolian-alluvial deposits, which are $12.5 \mathrm{~m}$ thick were analysed and three different facies in this succession described. The lowermost facies A highlights a strong aeolian influence marked by an increased silt percentage and was deposited during colder climate conditions. Sand and gravel in facies B were deposited by streams of dense, cold water formed by melting snow and ice from the nearby Dinaric mountains. The bioturbated sandy facies $C$ was probably formed during a warmer climate. An unusually high percentage of augite in the lowermost part of facies A can be explained by the input of volcanic dust, most likely from the Roman or Campanian volcanoes in Italy. This, combined with the surface textures on quartz grains detected from SEM photographs indicates a short distance transport for the sediment, no matter which mechanism was dominant. The sediments from Vrgada Island represent a transitional zone between the north Adriatic islands, where aeolian sediments dominate and the South - Eastern Adriatic archipelago, where mixed alluvial and aeolian sediments were observed.
\end{abstract}

Keywords: Pleistocene, aeolian,

\section{INTRODUCTION}

Pleistocene deposits may be found on many islands along the eastern Adriatic coast in the form of a thin, patch-like cover overlying Mesozoic and Palaeogene carbonate rocks. They are represented by various types of sediments including breccia, gravel, sand, loess-like sediment and sandy silt, deposited in subaqueous and subaerial environments (BOGNAR et al., 1992; MARJANAC \& MARJANAC, 2004; LUŽAR OBERITER, 2006; PAVELIĆ et al., 2006; PAVELIĆ et al., 2011; BABIĆ et al., 2013, PAVELIĆ et al., 2014). These deposits usually overlie small areas of insular karst dolines or they form vertical outcrops along the shoreline where their thickness rarely exceeds $10 \mathrm{~m}$. These various types of sediments are characterized by two main types of deposition: aeolian and alluvial (PAVELIĆ et al., 2011, 2014; BABIĆ et al., 2013).

Aeolian sediments were deposited during glacial or stadial dry climate intervals, while alluvial sediments were deposited during interglacial or interstadial warmer and wet climate conditions, indicating that their deposition was climate-driven (KOVAČIĆ et al., 2018). Aeolian and alluvial deposits repeat along the successions on some islands, but they also appear separately on others (BOGNAR et al., 1992; PAVELIĆ et al., 2011; BABIĆ et al., 2013). Pleistocene sediments formed by complex, dual depositional mechanisms also appear to crop out on Vrgada island (Fig. 1) in the form of coastal cliffs. The main goal of this study is to present a thorough analysis of the sedimentary chara-

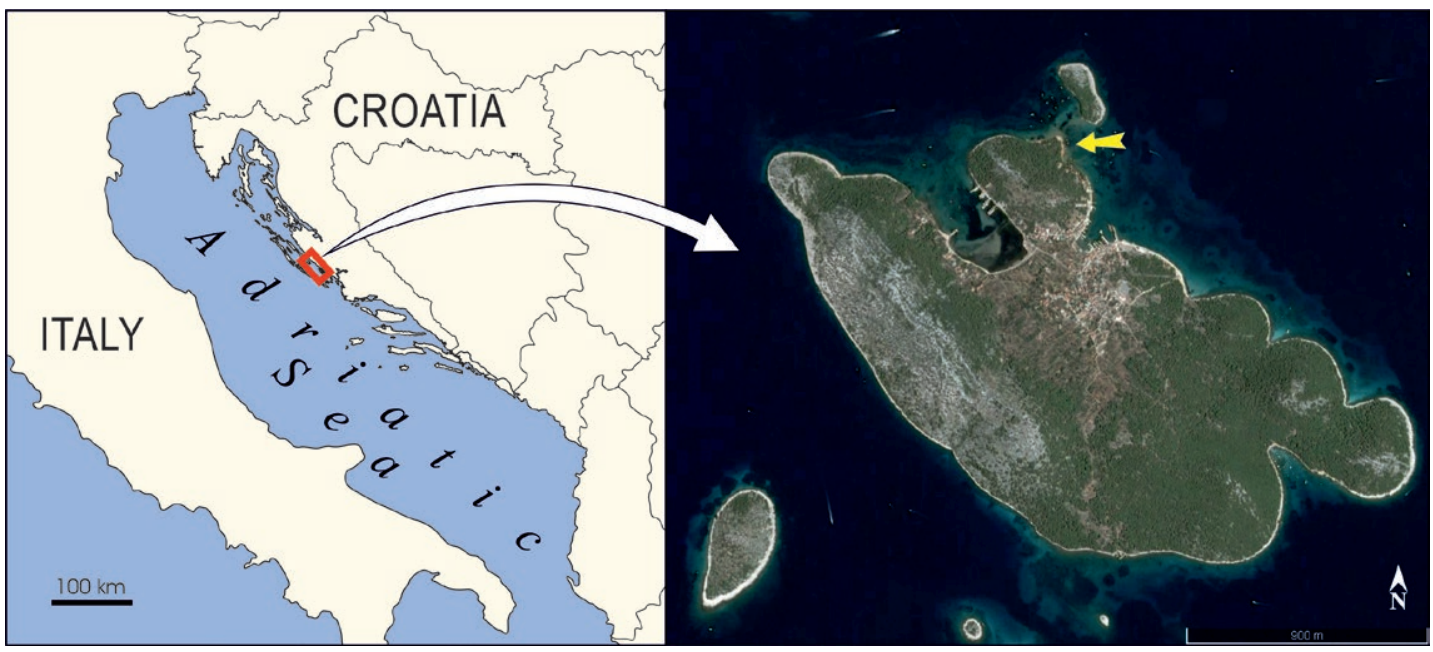

Figure 1. Location map showing the position of Vrgada Island and the investigated cliff on the northern part of the island, marked with a yellow arrow. 
cteristics of these Pleistocene sediments and define the sedimentary mechanisms that shaped them. In addition, we compare the sediments of Vrgada Island with similar deposits described from other islands situated along the eastern Adriatic coast.

Aeolian, silt-sized deposits are the dominant type of Pleistocene sediment in the northern part of the eastern Adriatic (CREMASCHI, 1990b; MIKULČIĆ PAVLAKOVIĆ et al., 2011; WACHA et al., 2011a). Loess-like sediment intercalated with sand is widespread and well described, especially on Susak Island where the sediment thickness exceeds $50 \mathrm{~m}$ (MIKULČIĆ PAVLAKOVIĆ et al., 2011; WACHA et al., 2011a). Together with the Padane area in northern Italy, this northern part of the eastern Adriatic coast formed a large "loess basin" during the Last glacial maximum (LGM), when global sea level was -135 m relative to the present sea level (CREMASCHI, 1990a; 1990b; PELTIER et al., 2006; CLARK et al., 2009). Most authors concluded that the LGM sea level in the Mediterranean was $120 \pm 5 \mathrm{~m}$ lower than at present (LAMBECK \& BARD, 2000; SURIĆ et al., 2005). This sea level drop exposed a vast, flat area of the northern Adriatic, which enabled the deflation of alluvial plain deposits of the Northern Adriatic shelf. The source area of material for this large alluvial plain was in the Alps and Apennines and sediments were transported by the paleo river Po.

Contrary to the northern part of the eastern Adriatic coast, its southern part which includes the islands of Hvar, Vis, Lopud, Mljet and Lastovo displays sand and gravel as the dominant types of Pleistocene sediment, in the form of dune sands, sand sheets and gravel-sand filled channels (BABIĆ et al., 2013; KOVAČIĆ et al., 2018). This group of islands is referred to as the South-eastern Adriatic (SEA) archipelago where aeolian sands were deposited in karst depressions, with the most complete sedimentary records occurring in the central parts of larger depressions (BABIC et al., 2013). Lopud Island is an exception, where the thickest sand and gravel deposits are located at the shoreline (KOVAČIĆ et al., 2018). The main source area for the SEA archipelago was the Dinarides and material was redeposited by strong southerly winds, so it is fundamentally different from the loess province of the northern Adriatic (BABIĆ et al., 2013; KOVAČIĆ et al., 2018).

Vrgada Island is situated in the central part of the eastern Adriatic coast (Fig. 1), between the northern Adriatic islands and the SEA archipelago. This makes it an interesting case study, as it represents a transitional zone in the sense of geography and sediment source area. This is why the alluvial - aeolian cliff deposits of Vrgada Island have been chosen for detailed study in order to improve the understanding of the depositional mechanisms and paleo-climate conditions during the Pleistocene in the central part of the Eastern Adriatic coast.

\section{GEOLOGICAL SETTING}

Vrgada Island is located in the middle part of the Croatian coast (northern Dalmatia), along the eastern part of the Adriatic Sea and it is a part of the Dinaric Mountain range (Fig. 1). Like the wider surroundings, Vrgada Island is composed of Cenomanian to Santonian shallow-water limestones (Fig. 2; MAMUŽIĆ \& NEDELA-DEVIDÉ, 1968; MAMUŽIĆ, 1982), deposited in carbonate platform environments formed on the Adria microplate, (detailed information is given in GUŠIĆ \& JELASKA, 1993; VLAHOVIĆ et al., 2002; 2005; KORBAR, 2009 and references therein). Accordingly, most of the coast of Vrgada Island is a steep and rocky carbonate coast, typical of the eastern Adriatic (PIKELJ \& JURAČIĆ, 2013). However, in several places (including the small Artina Island) Pleistocene clastic rocks crop out (Figs. 2 and 3). In this study, we focused on a N-S oriented coastal cliff, where the best outcrops are observed (Figs. 2 and 3). The total thickness of the outcrop is $12.5 \mathrm{~m}$, and its width is approximately $80 \mathrm{~m}$ (Fig. 3). The bottom of the outcrop is at $0.5 \mathrm{~m}$ a.s.l. and the top is at 13 $\mathrm{m}$ a.s.l. An up to $8 \mathrm{~m}$ wide sandy beach is developed in front of the studied part of the cliff (Fig. 3), as well as on its less steep E-W oriented part. Beach sediment is mostly reworked cliff material, subsequently distributed by longshore drift (PIKELJ \& FURČIĆ, 2020). The entire cliff top is vegetated with pine trees.

\section{METHODS}

\subsection{Field research}

Initial fieldwork took place in early June 2016, when the cliff was sampled every $25 \mathrm{~cm}$ for grain-size analysis and every $2 \mathrm{~m}$ for carbonate content, SEM and heavy mineral content. A total of 49 sediment samples were taken for various analyses.

The entire succession is covered by $1 \mathrm{~m}$ of modern soil (Fig. 3., on top of section B) and the lowest part of the sediment over-

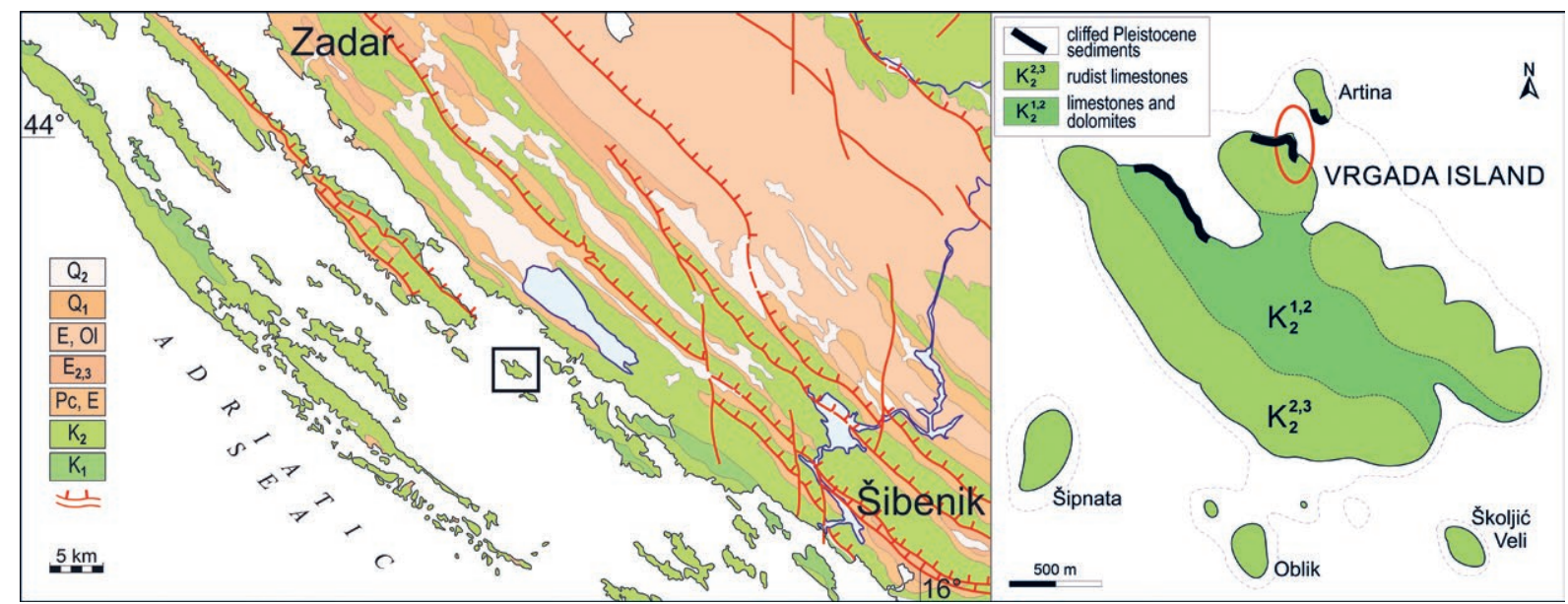

Figure 2. Geological map of Vrgada Island and the surrounding area of northern Dalmatia: $\mathrm{K}_{1}$ - Lower Cretaceous limestones and dolomites; $\mathrm{K}_{2}$ - Upper Cretaceous carbonate clastics, scaglia limestones and rudist limestones; Pc, E-Palaeocene and Eocene carbonate turbidites (flysch); Liburnia deposits, foraminiferal limestones and transitional deposits; $E_{2,3}$ - Eocene flysch; $E_{1}$ Ol-Eocene-Oligocene Promina beds and carbonate breccias; $Q_{1}$-Pleistocene fluvial and fluvioglacial deposits; $Q_{2}$ Holocene alluvial, lake and pond deposits; aeolian sands, terra rossa. Studied Pleistocene cliff sediments are marked by red oval (right picture). Sediments positioned in the north-west oriented bay are also Pleistocene (thick, black line), but their thickness is considerably less. 


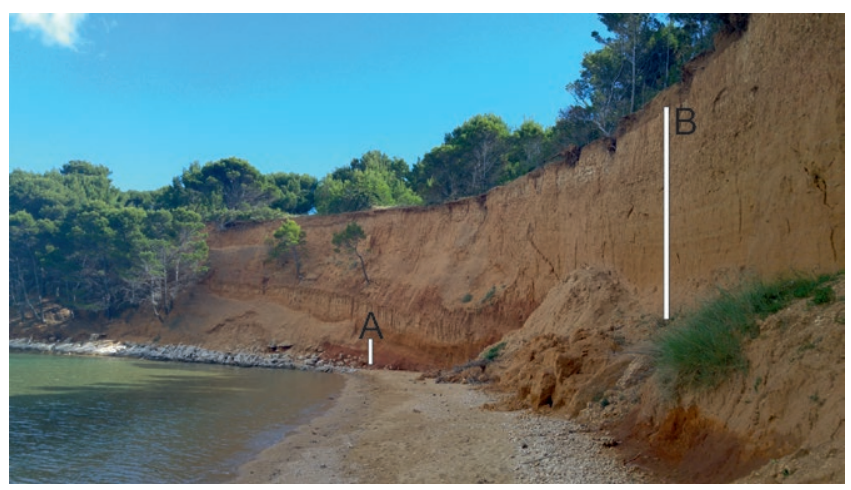

Figure 3. Outcrop of alluvial - aeolian sediment at the shoreline on Vrgada Island in the form of a coastal cliff. Sections A and B display the exact sampling locations. Note that the outcrop provides the mixed sandy-gravelly material for the approx. $8 \mathrm{~m}$ wide beach.

lies carbonate bedrock - Upper Cretaceous, rudist bearing limestones (Fig 3., section A). The investigated deposits are composed of sand, gravel, silt, and carbonate crusts, and form three, lithologically heterogeneous units in vertical succession (Fig. 3).

\subsection{Grain size analysis}

Grain size analysis was carried out on 49 samples in the Laboratory of the Croatian Geological Survey by the combined method of wet sieving (for particles $>63 \mu \mathrm{m}$ ) using ASTM standard stainless sieves and the pipette method (for particles $<63 \mu \mathrm{m}$ ). Grain size parameters (mean-Mz, median-Md, sorting-So, skewness-Sk and kurtosis-Kg) were calculated using the Gradistat statistic package (BLOTT \& PYE, 2001) according to the original FOLK \& WARD (1957) logarithmic graphical measures. In order to characterize the hydrodynamic conditions during sediment deposition, results of the grain size analysis were used to create a CM plot proposed by PASSEGA (1957). The CM plot is a binary plot of the coarsest one-percentile $(\mathrm{C}$; in microns) plotted against the median grain size (Md; in microns) on a log-probability scale. Results of the CM diagram are shown as "clouds" corresponding to the various transport and depositional conditions.

\subsection{Quantitative heavy mineral analysis}

Heavy minerals were separated from 7 sand samples following standard procedures (MANGE \& MAURER, 1992) using the 63-125 $\mu \mathrm{m}$ fraction previously treated with 5\% hydrochloric acid and tribromomethane (bromoform: density $2.89 \mathrm{~g} / \mathrm{cm}^{3}$ ). The heavy mineral fractions were mounted onto glass slides and approximately 250 transparent heavy mineral grains were identified per sample by ribbon counting under a polarizing microscope.

\subsection{Carbonate content}

The carbonate $\left(\mathrm{CaCO}_{3}\right)$ content was calculated from the weight difference before and after cold hydrochloric acid (5\%) treatment for each of the 7 samples that were also used for heavy mineral and SEM analysis.

\subsection{SEM analysis}

Photographs of quartz grains were taken using a scanning electron microscope (SEM) in the Laboratory of Geochemistry, INA oil Company. Previously extracted light mineral fractions from 7 sand samples were chosen for scanning electron microscopy. Sand grains were coated with a $25 \mathrm{~nm}$ thin gold layer and analysed using a scanning electron microscope JEOL, model JSM-
6510LV. More than 200 different grains were photographed, and the best images that show complete quartz grains were selected for further studies. Photographs were taken of the quartz grains in order to identify the shapes of the grains and inspect the detailed morphology of the grain surface. Microscopy was conducted within a magnification range of X100 - X950. In this study, the classification method and implemented terminology for quartz grain surface textures and shapes are based on studies of MAHANEY (2002), STRAND et al. (2003), STRAND \& IMMONEN (2010) and BANAK et al. (2013).

\section{RESULTS}

\subsection{Facies analysis}

The lower part of the outcrop up to the height of $4.8 \mathrm{~m}$ is dominated by silt and fine to medium-grained sand with a zone of FeMn concretions at $1 \mathrm{~m}$, a $30 \mathrm{~cm}$ thick sub-horizontal carbonate crust at the height of $3.1 \mathrm{~m}$ and a single thin gravel lens $(3 \mathrm{~cm})$ at $3.6 \mathrm{~m}$ (Figs. 4 and 5). This sediment is determined as facies A. Most of this facies, up to the height of $4 \mathrm{~m}$ (samples VR-49 to VR-33) is characterized by the moderate dominance of silt (approx. 51\%) compared to sand (approx. 40\%), while gravel was found to make up less than $5 \%$ throughout this entire interval. Only the uppermost part of the interval (samples VR-32 and VR31 ) is marked by the dominance of sand (approx. 62\%) over silt

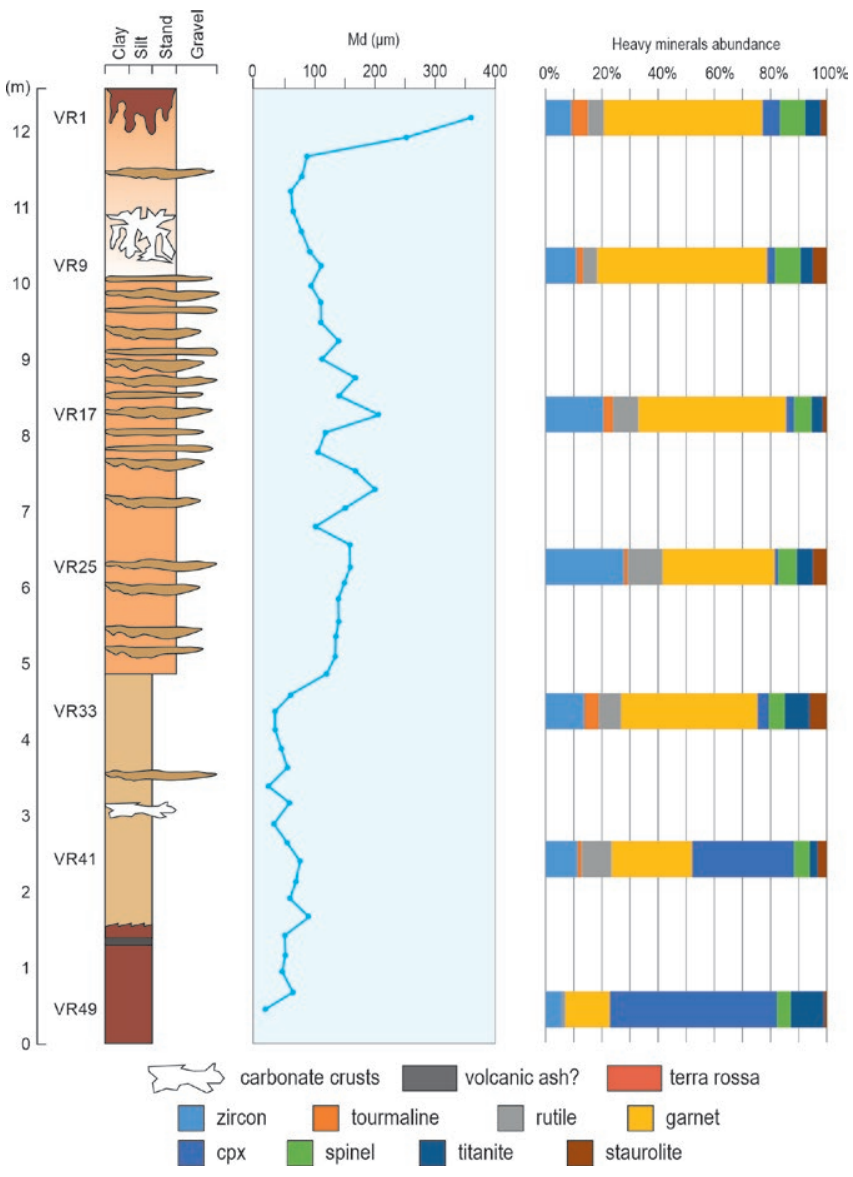

Figure 4. Details from the vertical succession on Vrgada Island. Facies A (samples VR-49 to VR-31) is dominated by silt and fine to medium - grained sand with a horizon of possible volcanic ash in terra rossa and a carbonate crust in the sand. Facies B (samples VR-30 to VR-9) is composed of mostly homogeneous sand and at least 13 gravel lenses and/or layers. Facies C (samples VR-8 to VR-1) at the top of the section is represented by medium to coarse grained sand which contains a carbonate crust of irregular shape and vertical, tube-like bioturbations; these last mostly abundant in the uppermost part. 

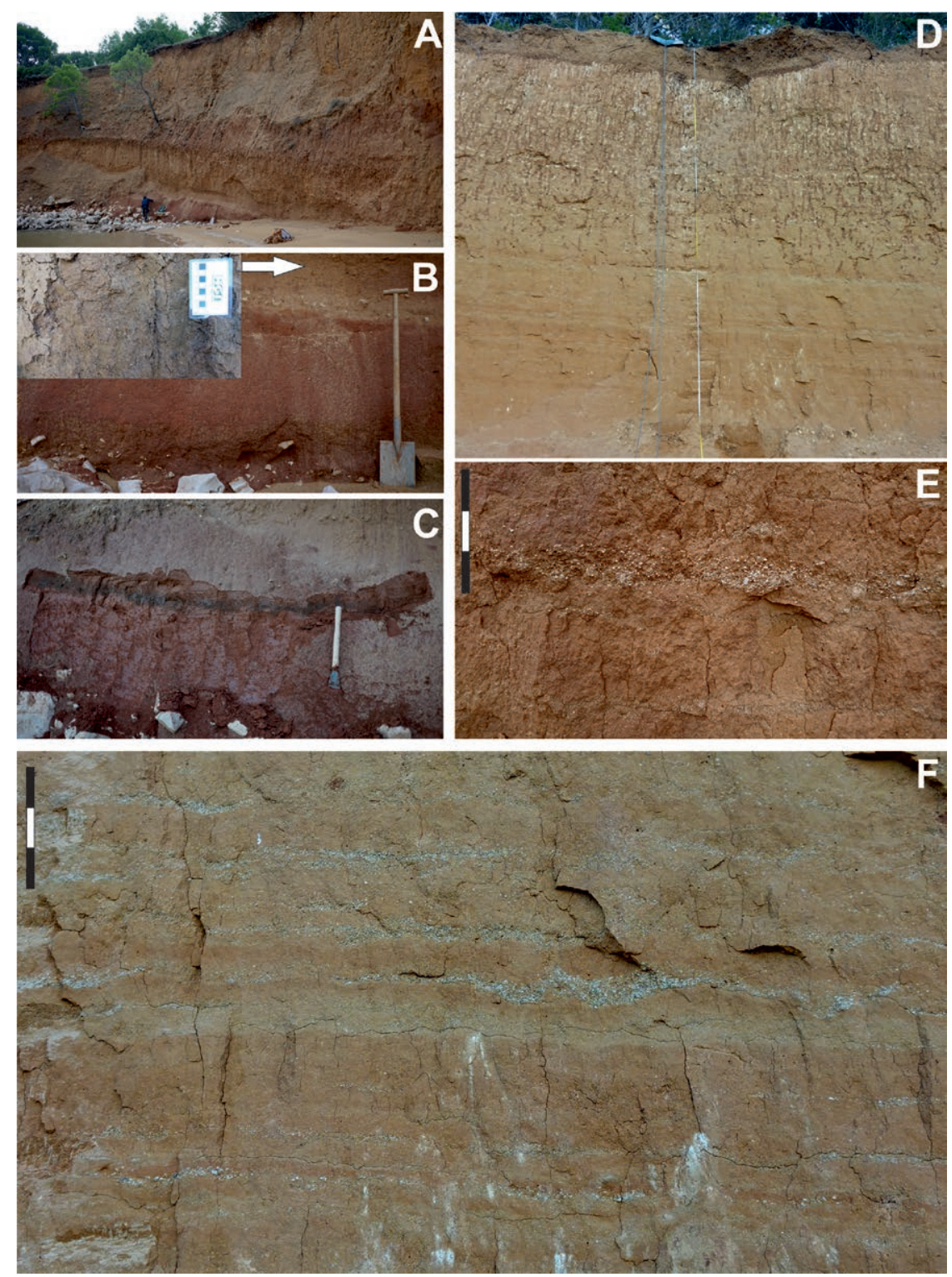

Figure 5. The different facies recognized during field research and after grain-size analysis. A) Overview photograph of the Vrgada Island outcrop. B) Terra rossa at the lowest part of facies A. Shovel for a scale is $1.2 \mathrm{~m}$ tall. Smaller photo shows $\mathrm{Fe}-\mathrm{Mn}$ concretions from silty sediment just above the terra rossa. C) Dark gray, 5 $\mathrm{cm}$ thick layer within terra rossa. D) Uppermost facies $C$ and the upper part of facies B. Note the tubular bioturbations at the top $1.5 \mathrm{~m}$. E) Close up of the middle part of facies B with a $20 \mathrm{~cm}$ gravel-sand unit displaying faint cross bedding topped by erosive channelised gravel unit. Graphic scale in the upper left corner is 30 $\mathrm{cm}$. F) Part of facies B with horizontally stratified sand and gravel horizons. Sand displays colour changes between yellowish and reddish varieties. Gravel units have sharp lower boundaries, often with channel forms or laterally extended undulatory surfaces. Graphic scale in the upper left corner is $30 \mathrm{~cm}$.

(approx. 32\%). A shift in the sand to silt ratio in this interval strongly affected the percentage of gravel, which dropped to $0 \%$, while the clay percentage slightly increased. Gravel lenses are not present in this interval of facies A. This facies, which is dominated by the finer particles of silt and fine to medium sand (Table 1), was formed by deposition from suspension that might also have contained some proportion of grains deposited by rolling (Fig. 6). In this facies, the sediment is homogeneous and poorly sorted, probably due to the smaller grain size of the particles and the twofold origin of sediment transport. The lowermost sample VR-49, which is the most fine-grained, with the maximum percentage of clay (24\%) and up to 54\% of silt represents terra rossa (Figs. 4 and 5). This is a reddish clayey to silty-clayey soil developed on top of limestones and it is widespread in the Mediterranean region (DURN et al., 1999). Terra rossa is defined as a polygenetic relict soil, formed during the Palaeogene, Neogene and/ or hot and humid periods of the Quaternary (ATALAY et al.,
1997; DURN et al., 1999). The high clay percentage recorded at the bottom of this facies is probably a consequence of a redistribution and possible redeposition of the terra rossa on which the silt was deposited. A conspicuous dark coloured layer several centimetres thick, possibly representing a tephra horizon is intercalated within the otherwise red terra rossa horizon (Fig. 5C). Close inspection in the field and later microscopic observations revealed that the material contains prismatic augite and abundant, sand-sized biotite grains, which are commonly euhedral (Fig. 8).

Facies B consists of overall horizontally stratified sand and gravel horizons, interfingering in the form of channel type lenses (Fig. 4 and Fig. 5). This is observed from $4.8 \mathrm{~m}$ up to $10 \mathrm{~m}$ (samples VR-30 to VR-9) in the cliff face. The boundary with facies $\mathrm{A}$ is neither sharp nor erosional, but rather a gradual transition from fine to medium-grained sand to coarse-grained sand as seen from grain size analysis. The first gravel lenses appear $30 \mathrm{~cm}$ from the top of facies A, but they are barely visible and rather 
thin, only 2 to $3 \mathrm{~cm}$. Most of the gravel lenses are present from a height of $5.6 \mathrm{~m}$ and to the boundary with facies C. Mostly homogeneous, medium to coarse-grained, poorly to very poorly sorted sands are dominant in this part of the succession. They are seemingly without any structures and display vertical colour changes and mottling between yellowish and reddish varieties suggestive of pedogenic processes (Fig. 5D and F). At least 17 visible, subhorizontal gravel lenses and/or layers displaying channel forms and occasional faint cross-bedding are observed in this facies (Fig. 5F). They rarely exceed $10 \mathrm{~cm}$ in thickness. Most of the lenses do not have continuous extension through the entire out- crop, but wedge out laterally. Channel forms are both gravel dominated and complex gravel-sand units occasionally with crude cross bedding (Fig. 5E). Gravel textures include a clast supported open framework, bimodal grain supported, and matrix supported varieties. The lower boundaries of the gravel units are sharp, often in the form of channels or laterally extended undulatory surfaces. These surfaces appear to have been amplified by soft-sediment deformation where the gravels are depressed into the underlying sand. Gravel clasts are $0.5-3 \mathrm{~cm}$ in size and dominantly angular, with a smaller percentage of sub-rounded ones. Laboratory analysis revealed that the clasts are of carbonate com-

Table 1. Grain size statistics and textural parameters of the studied Vrgada cliff sediment. (Legend for the sediment type: gmS - gravelly muddy sand; mS - muddy sand; (g)Ms -slightly gravelly muddy sand; sM - sandy mud; (g)sM - slightly gravelly sandy mud; gM - gravelly mud). Note: sample VR-49 is the bottom-most, while VR-1 is the top-most sample.

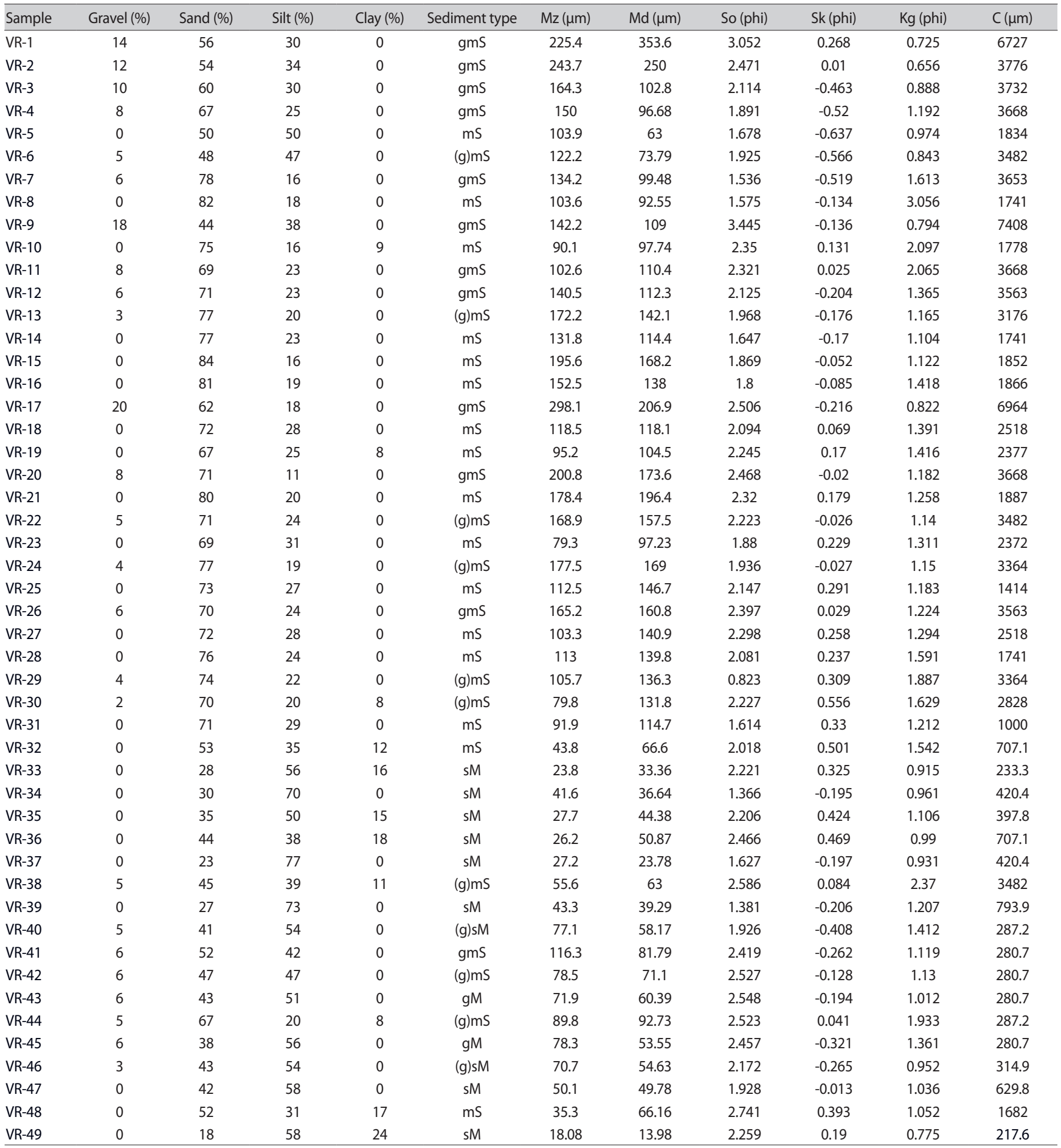


position. This sediment can be compared with alluvial non-confined and channel deposits generated from ephemeral streams (flash floods) identified in the SEA archipelago (BABIĆ et al., 2013, PAVELIĆ et al., 2014).

The uppermost part of the sediment succession (samples VR-8 to VR-1) consists of a $2.5 \mathrm{~m}$ thick interval marked by fine to medium grained sand and gravel which have been largely altered by an array of vertical, tube-like bioturbations and a carbonate crust (Fig. 4 and Fig. 5). This sediment is defined as facies C. Modern soil, which is approx. $1 \mathrm{~m}$ thick overlies this facies. The lower part of the facies, between 10 - 11 metres, is characterized by a branched, carbonate crust of irregular shape. The character of the boundary with facies B is unclear because the primary structures are altered. In the middle of this interval there is only one clearly visible gravel lens which is $5 \mathrm{~cm}$ thick. Two cycles with decreasing gravel percentage from the top to the bottom (Table 1) are detected in facies C. Bioturbations in the form of vertical, tubular feature throughout the whole succession, but are most dense in the top $60-70 \mathrm{~cm}$ of the interval. They are brown coloured and filled with silt sediment. The density of the carbonate crust structures and bioturbations have completely destroyed the original internal structure of the sand, especially in the uppermost and the lowest segment (Fig. 5E).

Changes in colour of the sediment were detected throughout the succession (Fig. 5). Using the Munsell colour chart we distinguished an almost regular change in facies (A), (B) and (C). The colour change ranges from 5 YR $5 / 8$ to 7.5 YR 5/6. Other variations in colour, but not represented in many horizons include $5 \mathrm{YR}$ 5/6, 2.5YR 4/8, 2.5YR 3/6 and 7.5YR 4/4 (all are yellow- red). The lowermost part of facies $(\mathrm{C})$ is represented by yellowish red coloured sediment, defined as 5YR 5/8 in the Munsell colour chart.

\subsection{Grain - size results}

Results of the grain size analysis and the textural parameters obtained are summarized in Table 1. In general, sand and silt dominate in all samples with averages of $58.7 \%$ and $34.8 \%$, respectively. The average percentage of gravel is $3.7 \%$, with a higher proportion in samples from the upper part of the succession, showing almost regular cycles of high and low percentages of gravel. The sediment texture shows a gradual decreasing downward trend in the gravel fraction, whereas the clay content exhibits the opposite trend with samples in its lower part containing up to $24 \%$ of the clayey fraction.

Calculated median (Md) and mean size (Mz) clearly separate the upper part of the outcrop (samples VR-1 to VR-30) as being coarser, with values generally above 100 microns for both parameters. In contrast, samples from the lower part (VR-31 to VR-49) have median and mean sizes below 100 microns (the exception is sample VR-41). Accordingly, prevailing sediment types in the upper part are sands (muddy sands; gravelly muddy sands; slightly gravelly muddy sands), while muds (sandy muds, gravelly sandy muds; slightly gravelly sandy muds) prevail in the lower part of the cliff (Table 1).

The sediment has been characterized to be poorly to very poorly sorted with So ranging mostly between $1.5-3$ with an average value of 2.13 (Table 1). Skewness varies between $0.56-0.64$ (average of -0.01) indicating both the presence of finer and coarser fractions along the succession. Kurtosis ranges widely between 0.65 and 3.06 , with the distribution curves being mostly leptokurtic (average around 1.3).

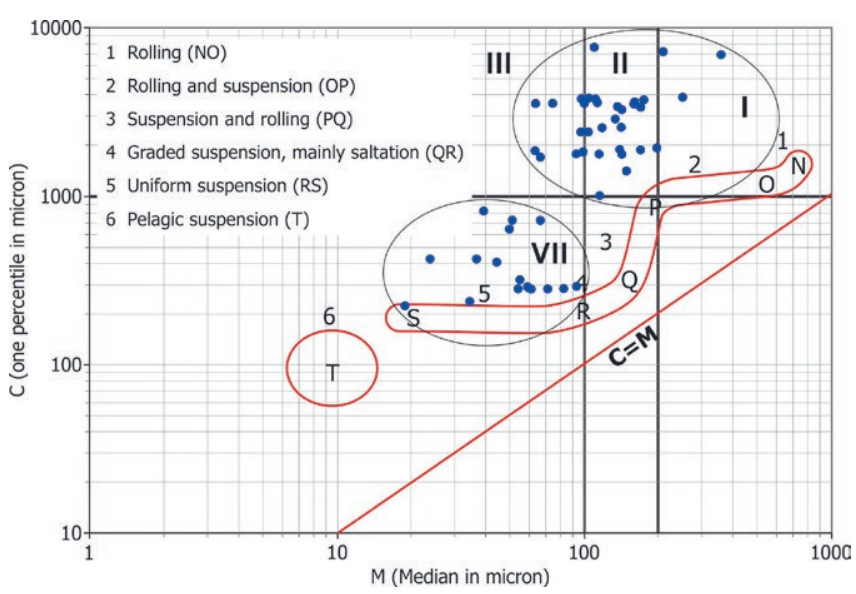

Figure 6. Transport mechanisms of the Vrgada sediments shown in the PASSEGA CM diagram. Fields labelled by roman numbers designate fields of various $C$ and $M$ values (e.g. for fields I-II-III C $>1000$ microns; for field VIII $M<100$ and $C<1000$ microns).

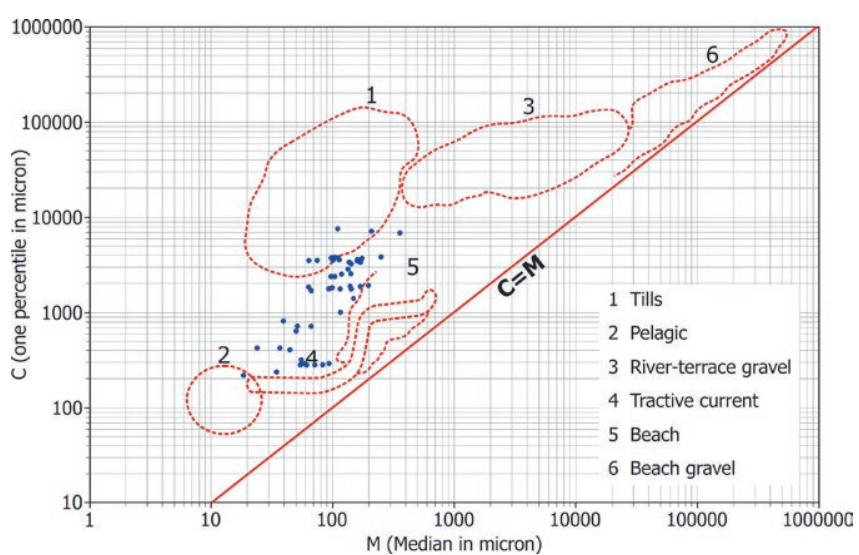

Figure 7. Depositional environments of the Vrgada sediments shown in the PASSEGA CM diagram. As for the depositional environment shown in Figure 7, CM plot indicates that the Vrgada sediments were deposited by surface flow.

The CM plot shows that all samples are distributed in fields corresponding to transport by tractive currents (Fig. 6 and Fig. 7), forming the "step" between uniform suspension (RS) and rolling (NO). The environmental conditions for the upper 30 coarser samples indicated deposition of sediment from both rolling (NO) and suspension and rolling (OP and $\mathrm{PQ}$ ). These samples have values of C $>1 \mathrm{~mm}$ (falling in fields I, II and III; Fig. 6), confirming that they contain grains either transported and deposited by rolling or deposited near the sediment source (PASSEGA \& BYRAMJEE, 1969). The rest of the finer samples fell in field VII (Fig. 6) indicating that these grains were deposited from suspension that might contain some rolled grains $<1 \mathrm{~mm}$. These sediment samples correspond to fields RS (uniform suspension) and QR (graded suspension) fields on the CM plot.

\subsection{Heavy mineral assemblages}

Results of the quantitative heavy mineral analysis on 7 samples from the Vrgada succession are shown in Table 2. The identified transparent heavy mineral species include zircon, tourmaline, rutile, garnet, augite, $\mathrm{Cr}$-spinel, titanite, staurolite, and occasionally kyanite and epidote. All the samples contain essentially the same assortment of heavy minerals, however, the proportions of the individual mineral species such as garnet and augite show distinct differences between samples from the upper and lowermost part of the succession (Fig. 4 and Fig. 8). 
Table 2. Quantitative heavy mineral analysis of 7 selected samples from the Vrgada succession.

\begin{tabular}{|c|c|c|c|c|c|c|c|c|c|c|c|c|c|c|}
\hline \multirow{2}{*}{ Sample } & \multicolumn{3}{|c|}{ Heavy fraction $100 \%$} & \multicolumn{11}{|c|}{ Other transparent minerals 100\% } \\
\hline & Op & Lf & OT & $\mathrm{zr}$ & tu & ru & gr & $\mathrm{au}$ & $\mathrm{sp}$ & ti & st & ky & ep & un \\
\hline VR-1 & 60 & 1 & 39 & 9 & 5 & 6 & 53 & 6 & 9 & 5 & 2 & 1 & 2 & 2 \\
\hline VR-9 & 72 & 1 & 27 & 11 & 2 & 5 & 59 & 2 & 9 & 4 & 5 & & 1 & 2 \\
\hline VR-17 & 79 & 1 & 20 & 20 & 4 & 9 & 52 & 3 & 6 & 4 & 1 & & & 1 \\
\hline VR-25 & 58 & 3 & 39 & 27 & 1 & 12 & 39 & 1 & 7 & 6 & 5 & & & 2 \\
\hline VR-33 & 75 & 1 & 24 & 13 & 5 & 8 & 47 & 4 & 6 & 9 & 6 & 1 & & 1 \\
\hline VR-41 & 58 & 2 & 40 & 11 & 1 & 10 & 28 & 35 & 6 & 3 & 3 & 1 & & 2 \\
\hline VR-49 & 57 & 3 & 40 & 6 & & 1 & 16 & 58 & 5 & 12 & 1 & & & 1 \\
\hline
\end{tabular}

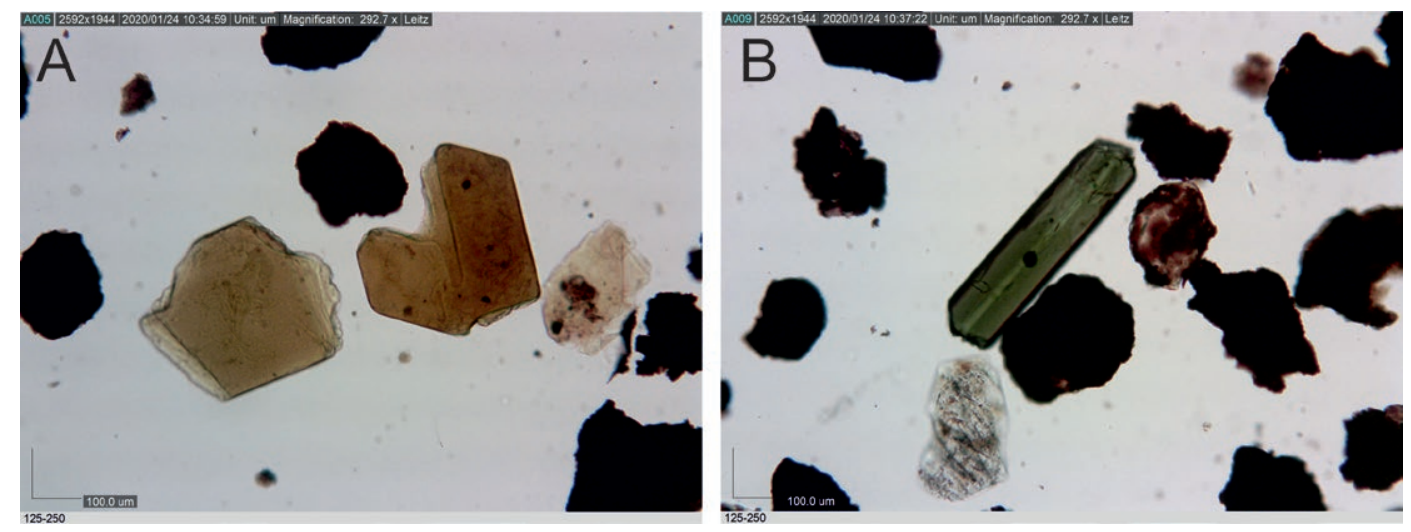

Figure 8. Abundant euhedral biotite grains $(A)$ and green augite $(B)$ from the conspicuous several centimetre-thick dark coloured layer within the lowermost terra rossa horizon.

\section{4. $\mathrm{CaCO}_{3}$ content}

The carbonate content in the samples varied significantly from $2.5 \%$ in the lowermost sample (VR-49) to $72.9 \%$ in the uppermost sample (VR-1), giving a mixed character to the studied deposits. The nature of carbonate grains needs to be further investigated in order to determine their source(s). The average $\mathrm{CaCO}_{3}$ value for facies $\mathrm{A}$ is $21.76 \%$, for facies $\mathrm{B}$ is $53.88 \%$ and for facies $\mathrm{C}$ is $59.83 \%$.

\subsection{SEM analysis of quartz grains}

All scanned and photographed quartz grains from the Vrgada outcrop are sand-sized particles $(>63 \mu \mathrm{m})$. In all the seven samples, angular grains dominate (Fig. 9). Their proportion is over $60 \%$ of the total number of grains in the samples. Around $5 \%$ of grains are very angular or sub-angular. Rounded and wellrounded grains make up to another $5 \%$. Over $70 \%$ of the grains in all samples are of low sphericity. On most grains, conchoidal fractures and $\mathrm{V}$-shaped percussion marks were visible. Conchoidal fractures were detected in over $50 \%$ of the grains in the samples (Fig. 9). A small number of grains showed conchoidal fractures that are nearly the size of the length of the longer axis of the grain, while the majority of grains had conchoidal fractures with $1 / 3$ of that dimension. V-shaped percussion marks were visible on only 3 individual grains. The size of these surface micro textures is in the range of 2-5 $\mu \mathrm{m}$. They are usually clustered on smooth, flat surfaces of grains in groups that consist of 3 to 5 marks. About $10 \%$ of all grains display sets of parallel striations. The length of striation marks is on average between 15 and 20 $\mu \mathrm{m}$ and sets consist of 5 to 6 striations on average. Upturned plates are observed on more than $10 \%$ of grains.

\section{DISCUSSION}

Sediments from the Vrgada outcrop are divided into 3 different facies: A, B and C. Grain size analysis of facies A, B as well as the upper part of facies $\mathrm{C}$ indicate deposition of sand and gravel by both, rolling (NO) and suspension and rolling (OP and PQ) which is supported by SEM analysis of sandy quartz grains (Figs. 6, 7 and 9).

Aeolian transport was dominant in this facies at least in the lower and middle interval, as the mineral assemblage with an increased percentage of augite (Table 2; Fig. 8) and SEM images of quartz grains (Fig. 9) suggest. The occurrence of gravel could represent a fluvial channel incised into the sandy silt, a feature encountered at other localities of Pleistocene deposits along the Adriatic coast (see BABIĆ et al., 2013). Based on the grain size distribution, sediment from this facies can be compared to sandy loess horizons from Susak Island (MIKULČIĆ PAVLAKOVIĆ et al., 2011). The carbonate content of $21.76 \%$ is also comparable to that from Susak island which is in the range of $14.9 \%-25 \%$ (MIKULČIĆ PAVLAKOVIĆ et al., 2011).

Sand from facies B is similar to Lopud island (southern-eastern Adriatic) structureless sands from Unit U3, deposited by traction from sheet flows in an unconfined stream (KOVAČIĆ et al., 2018). The lack of lamination in sands from facies $B$ could be a consequence of diagenetic processes following deposition (WALKER et al., 1978), which is possible considering the changes in sediment colour and mottling that are visible throughout this facies. Channel type, gravel lenses and gravel-sand units from facies B can be compared with alluvial non-confined and channel deposits generated from ephemeral streams (flash floods) identified in the SEA archipelago islands (BABIĆ et al., 2013; PAVELIĆ et al., 2014; KOVAČIĆ et al., 2018). Gravel-sized clasts within channel type lenses point to a repeated, almost regular increase in water energy (stronger floods) and transport by rolling from locally exposed carbonate highs or the Dinaric mountains. The silt sized fraction from facies B is likely deposited from sus- 

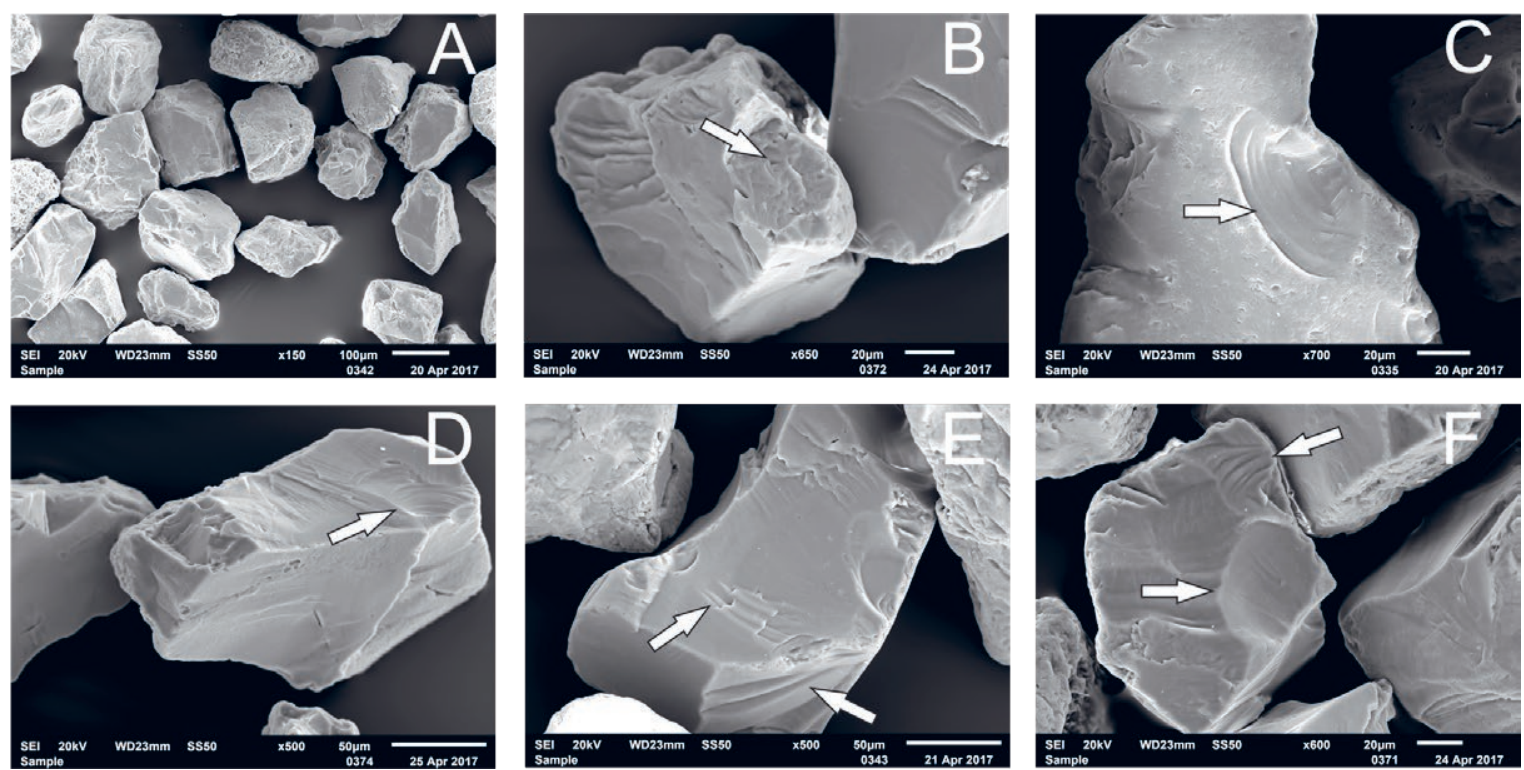

Figure 9. Morphology of grain surfaces on selected quartz grains from the Vrgada outcrop. A) Overview of sand sized, quartz grains from facies B. Angular and subangular grains dominate. B) V-shaped percussion marks on the surface of the quartz grain from facies B. C) Conchoidal fracture on the grain from facies A. D) Conchoidal fracture on the sub angular grain from facies B. E) Parallel striations on a large flat surface and upturned plates at the bottom of the angular grain. F) Conchoidal fracture on the right side of the grain from facies A. Radial steps are visible at the upper edge.

pension and weak traction currents in a pond (NEMEC \& STEEL, 1984; PLATT \& KELLER, 1992).

It is possible that the sand-gravel body from facies B is the result of sediment transport and deposition within dense and cold water (HARASIMIUK, 1991; GAUDIN et al., 2006). These cold, dense water flows probably originated from the melting of snow and ice in the Dinaric mountains which are located nearby, in the hinterland of Vrgada Island (MARJANAC \& MARJANAC,
2004; KRKLEC et al., 2015). These flows could wash out the sediment deposited in flattened areas at the foothills of the Dinaric mountains and transport it over relatively short distances to the present-day location of Vrgada Island. During the Upper Pleistocene, the area of Vrgada Island was most likely connected to the mainland, because the sea level fluctuated and it was significantly lower compared to the present day, even during the warmer periods of the Pleistocene (LAMBECK \& BARD, 2000;
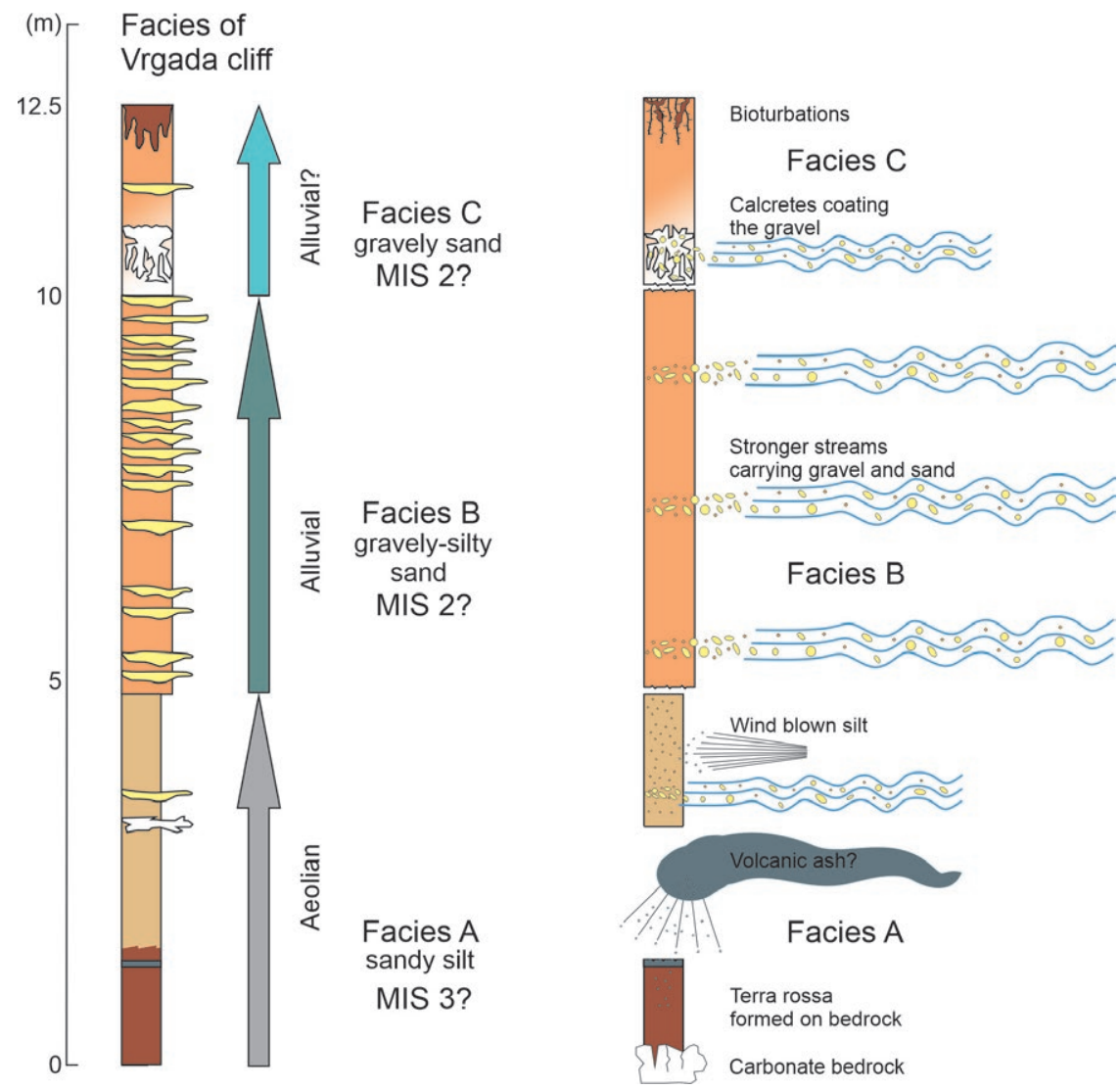

Figure 10. Facies A, B and C from the Vrgada island cliff with a schematic presentation of the different depositional mechanisms. 
SURIĆ et al., 2005). Exact dates of flood events are not known, but a recent study from the southern part of Velebit Mountain 40 $\mathrm{km}$ to the South yielded an age of $20.7 \pm 2.2 \mathrm{ka}$ to $22.7 \pm 2.7 \mathrm{ka}$ BP, for the retreat of glaciers (SARIKAYA et al., 2020). Dating was performed by cosmogenic $36 \mathrm{Cl}$ chronology from a moraine complex known as the Rujanska Kosa. The authors used $20 \mathrm{~mm}$ $\mathrm{ka}-1$ erosion corrected ages for carbonate boulders, as the study area is composed of well-karstified carbonate deposits and located in one of the highest precipitation regions of Europe. Based on their results we can tentatively suggest that the sediment from facies B could have been deposited shortly after the glaciers started to melt and retreat, during the last glacial maximum LGM (SARIKAYA et al., 2020).

Based on the shape, relief, roundness (or angularity) and surface micro textures of sand-sized quartz grains, we can conclude the following: grains with sharp edges, angular or sub-angular in shape and with medium to high relief are dominant in all three facies. Conchoidal fractures which are present in most of the grains, are the product of glacial processes and aeolian transport of silt and sand. The smaller number of grains exhibiting socalled V-shaped percussion marks on their surfaces resulted from bouncing and collision between grains in the process of saltation during aeolian transport. They can also be the product of the same process in rivers and streams with high water energy (MAHANEY, 2002). A small number of grains with visible sets of parallel striations suggest glacial abrasion of grains under the pressure of ice (MAHANEY, 2002). Grains from facies A display surface textures typical for aeolian transport, while grains from facies B and facies C display surface textures which point to mixed, alluvial-aeolian transport. The combination of surface textures on the quartz grains from the Vrgada outcrop indicates a short transport distance for sediment no matter which mechanism (aeolian or alluvial) was dominant.

Muddy and gravelly-muddy sands in facies C are strongly altered by numerous bioturbations and carbonate crust; therefore, it was not possible to recognize any original sedimentary structures (Fig. 10). As a consequence, the carbonate content is the highest in this part of the succession and grain size analysis displays high median values (Table 1 and Fig. 4). Sorting is poor throughout the facies, regardless of grain-size (Table 1). Exact processes leading to cementation and the formation of carbonate crusts are not completely determined, however, they partially include the dissolution of calcareous material by pore waters in buried sediments, followed by the precipitation of calcite during compaction (MARSHALL \& PIRRIE, 2013). Carbonate crusts or calcretes are soil related phenomena and much of the calcium carbonate derives from dust (DORN, 1998). They typically form when a mineral precipitates and cements sediment around a nucleus, which is often organic, such as a leaf, tooth, root, or fossil (MOZLEY \& DAVIS, 2005), but can also be a gravel clast (DORN, 1998). It is very likely that the process of crust forming began with the formation of a thin calcium carbonate coating around the gravel clasts that are present in facies C. Thin coatings grow first on clast undersides and over time, coatings become more continuous on the upper and lower sides (DORN, 1998). Gradually, pore spaces between the gravel clasts infill with carbonate and when the pores are blocked, a horizon of laminar calcrete precipitates on top of the impermeable soil (DORN, 1998). Bioturbations which permeate almost the whole of facies C probably correlate to the most recent Holocene age, reflecting increased biological activity near the present-day surface.
Heavy mineral assemblages provided information regarding the source of the siliciclastic material found in the Vrgada sediments. Samples from the upper part of the studied section (facies C and upper part of facies B) are strongly dominated by garnet which regularly constitutes more than $50 \%$ of the transparent heavy minerals, while zircon, $\mathrm{Cr}$-spinel, augite, titanite, tourmaline and rutile each make up roughly $1-10 \%$ (up to $27 \%$; Table 2, Fig. 4). The specific carbonate-dominated lithological makeup of the recent eastern Adriatic coastlines hides the potential sources of considerable siliciclastic material arriving from the direction of the Dinarides to the east. Nevertheless, the observed assemblages clearly indicate that the siliciclastic material most likely derived from the erosion of garnet rich Eocene sandstones in clastic deposits which stretch along the eastern Adriatic coast and islands (Fig. 2; MAJCEN \& KOROLIJA, 1973; PAVIČIĆ et al., 2000; 2003). Considering that these source rocks are not exposed on Vrgada Island, the material was probably transported to the studied location by combined alluvial and aeolian mechanisms during times when the sea level was considerably lower. The absence of epidote and hornblende indicates that northern Italian rivers, including the Po, which otherwise supplied most of the Quaternary sediments of the northern Adriatic Sea bottom and some of the northern Adriatic islands (PIGORINI, 1968; MIKULČIĆ PAVLAKOVIĆ et al., 2011), did not contribute material to the studied part of the eastern Adriatic coastal area. This includes the westerly rivers draining the northern Apennines which along with garnet also carry substantial amounts of epidote and amphiboles, but also characteristic minerals such as glaucophane (RIZZINI, 1974). The pyroxene-amphibole dominated Albanese province of the southeastern Adriatic, which sourced Pleistocene sands of the SEA archipelago, is also an unlikely source (BABIĆ et al., 2013).

Unlike samples from the upper two facies in the cliff, those from the lowermost facies A of the section contain a conspicuously high percentage of green clinopyroxene (augite), exceeding $50 \%$. The remainder of the heavy mineral fraction is composed of the same assortment of minerals as in other samples. This addition of clinopyroxene can be explained by volcanic input, from the Roman or Campanian volcanoes in Italy (PIGORINI, 1968; POUCLET et al., 1999; HORVÁTH, 2001), with the Campanian Province as the most probable source area (CALANCHI \& DINELLI, 2008). This increase in augite occurs in the terra rossa, in the lowermost part of facies A of the studied section. This sediment is characterized by a dominance of silt, where sedimentation rates were probably lower and most of the siliciclastic input can be attributed to aeolian processes. DURN et al. (2007) concluded that in some isolated karst terrains, terra rossa may have formed exclusively from the insoluble residue of limestone and dolomite, but most often it comprises a variety of materials, which in terra rossa from the Istrian peninsula are Middle Pleistocene loess, flysch, tephra and reworked bauxites. Due to the grain-size, mineral composition and colour of the terra rossa from Vrgada Island, this proposed model of external material influx can also be applied in our research.

The conspicuous, $5 \mathrm{~cm}$ thick, dark grey coloured layer encountered within the otherwise red terra rossa horizon is rich in biotite and green augite and may represent a possible tephra horizon. It is likely that volcanic material which settled from an eruption cloud has been partly mixed into the background sediment at the Vrgada site by pedogenic processes, and remains concentrated in the possible tephra horizon described above. Tephra layers are a common feature of Pleistocene deposits along the 
Table 3. Comparison of main characteristics of Vrgada Island deposits with two previously described sedimentary provinces of the eastern Adriatic coast.

\begin{tabular}{llll}
\hline & Northern Adriatic & Vrgada Island & SEA archipelago \\
\hline Dominant deposits & sandy loess, loess like sediment & silty sand with gravel lenses & dune sands, sand sheets \\
Main heavy minerals & amphibole, epidote, garnet & garnet, zircon, augite & clinopyroxene, orthopyroxene, amphibole \\
Tephra occurance & yes & possible & yes \\
Source area & Alps, Apennines & Dinarides, Alps? & Dinarides \\
\hline
\end{tabular}

Croatian coast and have been identified at numerous localities (MIKULČIĆ PAVLAKOVIĆ et al., 2011; BABIĆ et al., 2013; KOVAČIĆ et al., 2018).

Due to the absence of absolute dating on the potential tephra horizon, the exact age of this material from Vrgada island remains unclear. However, based on the presence of idiomorphic green augite in dark grey coloured aeolian silt, the "tephra" from Vrgada island could be correlated with the youngest, greyish tephra layer dated at $29.1 \mathrm{ka}$ (WACHA et al., 2011b) from Susak Island, which is located approx. $100 \mathrm{~km}$ to the north west. This points to an Upper Pleistocene age, possibly to MIS 3 for the sandy silt from facies A. Accordingly, and coupled with the latest study of SARIKAYA et al. (2020) sand and gravel from facies B and facies $\mathrm{C}$ are younger, and the age of the sediment is probably MIS 2 or LGM.

By means of lithology Upper Pleistocene deposits on the Vrgada Island are somewhat similar to those of Lopud Island (KOVAČIĆ et al., 2018) in the southern part of the Adriatic (Table 3), because sand is a dominant fraction and the outcrops are located at the shoreline of both of the islands.

\section{CONCLUSION}

This study presents preliminary results and the first description of the Pleistocene sediment succession of the coastal cliff situated on the eastern mid-Adriatic Vrgada Island. Studied sediments form a vertical, $12.5 \mathrm{~m}$ thick succession composed of alluvial sand intercalated with more than 20 channel type gravel lenses deposited on top of silty, aeolian material and containing a potential tephra layer at the very bottom.

Three different facies were identified and described. Lowermost facies A has a strong aeolian influence marked by an increased silt percentage and was deposited on top of terra rossa during colder climate conditions. Sand and gravel in facies B were presumably deposited from sheet flows generated by the melting and retreat of nearby glaciers from the Dinaric mountains. Bioturbated and concretion-rich sandy facies $\mathrm{C}$ was probably formed during a warmer climate.

Results of modal analysis show that garnet rich Eocene sandstones from the flysch basins in Dalmatia are likely to have been the source area for the siliciclastic material deposited on Vrgada Island. An unusually high percentage of augite (58\%) in the lowermost part of facies A can be explained by volcanic input, from the Roman or most likely Campanian volcanoes in Italy, which was later mixed into the background sediment. The combination of surface textures on quartz grains detected with SEM indicates a short transport distance for the sediment, no matter which mechanism (alluvial or aeolian) was dominant. Correlation of the possible tephra horizon from Vrgada island with tephra layers on other Adriatic islands suggests an Upper Pleistocene age for the sediment of facies A. Vrgada Island sediments composed of three different facies represent a transitional zone between the north Adriatic islands, where aeolian sediments dominate and the SEA archipelago where mixture of alluvial and aeolian sediments are observed.

The eastern Adriatic coast is mostly described as a karstic hard rocky coast; however, results of this study provide new data about the geological structure of its rare segments developed in soft rocks. New insight into the composition and origin of the studied succession will undoubtedly contribute to the understanding of coastal changes and coastal erosion on Vrgada Island as well as in similar coastal environments along the Croatian coast. Furthermore, the obtained results will provide valuable information for the production of new geological maps of the Republic of Croatia, which is currently underway. The results of this research form the basis for future research of similar sediments and the first step will be to date the potential tephra layer.

\section{ACKNOWLEDGEMENT}

This paper was partially supported by Projects no. 181-181-10961093, 195-1951293-2703 and 195-1951293-0237 of the Croatian Ministry of Science, Education and Sports. Hereby we express our thanks to Nikola ŠOIĆ for his assistance in taking samples from the vertical cliff by applying alpine climbing techniques. We are grateful to Robert KOŠĆAL for his assistance in artwork preparation. We thank the reviewers whose advice and corrections helped us to significantly improve the second version of the manuscript.

\section{REFERENCES}

ATALAY, I. (1997): Red Mediterranean soils in some karstic regions of Taurus mountains, Turkey.- Catena, 28/3-4, 247-260. doi: 10.1016/S0341-8162(96)00041-0

BABIĆ, LJ., ZUPANIĆ, J., VIDOVIĆ, J., RAZUM, I., LUŽAR-OBERITER, B. \& CRNJAKOVIĆ, M. (2013): Preservation of hanging aeolian deposits in insular karst depressions: Sediment sources and implications for the Pleistocene palaeogeography of the SE Adriatic archipelago.-Aeol. Res., 11, 171-189. doi: 10.1016/j. aeolia.2013.06.003

BANAK, A., PAVELIĆ, D., KOVAČIĆ, M. \& MANDIC, O. (2013): Sedimentary characteristic and source of loess in Baranja (Eastern Croatia).-Aeol. Res., 11, 129-139. doi: 10.1016/j.aeolia.2013.08.002

BLOTT, S.J. \& PYE, K. (2001): GRADSTAT: A Grain Size Distribution and Statistics Package for The Analysis of Unconsolidated Sediments. Earth Surface Process.Landforms, 26, 1237-1248.

BOGNAR, A., KLEIN, V., MESIĆ, I., CULIBERG, M., BOGUNOVIĆ, M., SARKOTIĆ-ŠLAT, M. \& HORVATINČIĆ, N. (1992): Quaternary sands at the south-eastern part of the Mljet Island.- In: BOGNAR, A. (ed.): Proceedings of the International Symposium 'Geomorphology and Sea' and the Meeting of the Geomorphological Commission of the Carpatho-Balkan Countries. Department of Geography, Faculty of Science, University of Zagreb, Zagreb, 99-110.

CALANCHI, N. \& DINELLI, E. (2008): Tephrostratigraphy of the last 170 ka in sedimentary successions from the Adriatic Sea.- J. Volc. Geoth. Res., 177, 81-95. doi: 10.1016/j.jvolgeores.2008.06.008

CLARK, P.U., DYKE, A.S., SHAKUN, J.D., CARLSON, A.E., CLARK, J., WOHLFAHRT, B., MITROVICA, J.X., HOESTETLER, S.W. \& McCABE, A.M. (2009): The Last Glacial Maximum.- Science, 325, 710-714. doi: 10.1126/science. 1172873

CREMASCHI, M. (1990a): The loess deposits in Northern and Central Italy: a loess ba$\sin$ between the Alps and the Mediterranean regions. - In: CREMASCHI, M. (ed.): The Loess in Northern and Central Italy. Centro di Studio per la Stratigrafia e Petrografia delle Alpi Centrale. Editrice Gutenberg, Milan, 15-19.

CREMASCHI, M. (1990b): Stratigraphy and palaeoenvironmental significance of the loess deposits on Susak island (Dalmatian archipelago).- Quat. Int., 5, 97-106. doi: 10.1016/1040-6182(90)90029-4 
DORN, R.I. (1998): Rock coatings. Developments in Earth Surface Processes 6. Elsevier Science. Amsterdam, Netherlands, 429 p.

DURN, G., OTTNER, F. \& SLOVENEC, D. (1999): Mineralogical and geochemical indicators of the polygenetic nature of terra rossa in Istria, Croatia.- Geoderma, 91, 1-2, 125-150. doi: 10.1016/S0016-7061(98)00130-X

DURN, G., ALJINOVIĆ, D., CRNJAKOVIĆ, M. \& LUGOVIĆ, B. (2007): Chapter 28: Heavy and Light Mineral Fractions Indicate Polygenesis of Extensive Terra Rossa Soils in Istria, Croatia.- Dev. in Sed., 58, 701-737.

FOLK, R.L. \& WARD, W. (1957): Brazos river bar: a study in the significance of grain size parameters.- J. Sed. Petro., 27, 3-26. doi: 10.1306/74D70646-2B21-11D7$8648000102 \mathrm{C} 1865 \mathrm{D}$

GAUDIN, M., SERGE BERNÉ, JOUANNEAU, J.-M., PALANQUES, A., PUIG, P., MULDER, T., CIRAC, P., RABINEAU, M. \& IMBERT, P. (2006): Massive sand beds attributed to deposition by dense water cascades in the Bourcart canyon head, Gulf of Lions (northwestern Mediterranean Sea).--Mar. Geol., 234, 111-128. doi: 10.1016/j.margeo.2006.09.020

GUŠIĆ, I. \& JELASKA, V. (1993): Upper Cenomanian-Lower Turonian sea-level rise and its consequences on the Adriatic-Dinaric carbonate platform.- Geologische Rundschau, 82/4, 676-686.

HARASIMIUK, M. (1991): Vistulian glacial cycle of the fluvial processes development in the valley of the middle Wieprz River (SE Poland).-Annales UMCS, 46, 81-109.

HORVÁTH, E. (2001): Marker horizons in the loesses of the Carpathian Basin.- Quat. Int., 76/77, 157-163. doi: 10.1016/S1040-6182(00)00099-9

KORBAR, T. (2009): Orogenic evolution of the External Dinarides in the NE Adriatic region: a model constrained by tectonostratigraphy of Upper Cretaceous to Paleogene carbonates.- Earth. Sci. Rev., 96/4, 296-312. doi: 10.1016/j.earscirev.2009.07.004

KOVAČIĆ, M., PAVELIĆ, D., VLAHOVIĆ, I., MARKOVIĆ, F., WACHA, L., KAMPIĆ, F., RONČEVIĆ, S. \& DREMPETIĆ, D. (2018): Pleistocene alluvial and aeolian deposits with tephra on the island of Lopud (eastern mid-Adriatic, Croatia): Provenance, wind regime, and climate controls.-Quat. Int., 494, 92-104. doi: 10.1016/j.quaint.2017.11.054

KRKLEC, K., DOMíNGEZ-VILLAR, D. \& PERICA, D. (2015): Depositional environments and diagenesis of a carbonate till from a Quaternary paleo glacier sequence in the Southern Velebit Mountain (Croatia).- Palaeogeogr. Palaeocl. Palaeoec., 436, 188-198. doi: 10.1016/j.palaeo.2015.07.004

LAMBECK, K. \& BARD, E. (2000): Sea-level change along the French Mediterranean coast for the past 30000 years.- Earth. Plan. Sci. Lett., 175, 203-222. doi: 10.1016/ S0012-821X(99)00289-7

LUŽAR-OBERITER, B. (2006): Usporedba sastava i porijekla obalnih pijesaka otoka Hvara i Raba.- Unpublished MSc Thesis, University of Zagreb, 85 p.

MAHANEY, W.C. (2002): Atlas of Sand Grain Surface Textures and Applications.- Oxford University Press, $237 \mathrm{p}$.

MAJCEN, Ž. \& KOROLIJA, B. (1973): Explanatory notes for sheet Zadar, Basic Geological Map of Yugoslavia, 1:100000.- Federal Geological Institute, Belgrade, Croatian Geological Institute, Zagreb, 40 p.

MAMUŽIĆ, P. \& NEDELA-DEVIDÉ, D. (1968): Basic Geological Map of SFRY: Biograd Sheet, scale 1: 100.000, K33-7.-- Inst. geol. istraž., Zagreb (1963), Sav. geol. zavod Beograd.

MAMUŽIĆ, P. (1982): Basic Geological Map of SFRY: Šibenik Sheet, scale 1: 100.000, K33-8.- Inst. geol. istraž., Zagreb (1962-1965), Sav. geol. zavod Beograd.

MANGE, M.A. \& MAURER, H.F.W. (1992): Heavy Minerals in Colour.-Chapman and Hall, London, 151 p. doi: 10.1007/978-94-011-2308-2

MARJANAC, LJ. \& MARJANAC, T. (2004): Glacial history of Croatian Adriatic and coastal Dinarides.- In: EHLERS, J. \& GIBBARD, P.L. (eds.): Quaternary Glaciations - Extent and Chronology, Elsevier, 19-26. doi: 10.1016/S15710866(04)80053-8

MARSHALL, J.D. \& PIRRIE, D. (2013): Carbonate concretions-explained.- Geol. Today, 29, Issue 2, 53-62. doi: 10.1111/gto. 12002

MIKULČIĆ PAVLAKOVIĆ, S., CRNJAKOVIĆ, M., TIBLJAŠ, D., ŠOUFEK, M., WACHA, L., FRECHEN, M. \& LACKOVIĆ, D. (2011): Mineralogical and geochemical characteristics of quaternary sediments from the island of Susak (Northern Adriatic, Croatia).- Quat. Int., 234, 32-49. doi: 10.1016/j.quaint.2010.02.005

MOZLEY, P.S. \& DAVIS, J.M. (2005): Internal structure and mode of growth of elongate calcite concretions: Evidence for small-scale microbially induced, chemical heterogeneity in groundwater.- Geol. Soc. Am. Bullett., 117, 1400-1412. doi: 10.1130/B25618.1

NEMEC, W. \& STEEL, R.J. (1984): Alluvial and costal conglomerates: their significant features and some comments on gravelly mass-flow deposits.- In: COSTER, E.H. \& STEEL, E.H. (eds.): Sedimentology of Gravels and Conglomerates, vol. 5. Canadian Society of Petroleum Geologists Memoir, 597-604.

PASSEGA, R. (1957): Texture as characteristics of clastic deposition.- Am. Assoc. Petro. Geol. Bullett., 41, 1952-1984.

PASSEGA, R. \& BYRAMJEE, R. (1969): Grain-size image of clastic deposits.- Sedimentology, 11, 233-252.
PAVELIĆ, D., KOVAČIĆ, M. \& VLAHOVIĆ, I. (2006): Periglacial aeolian-alluvial interaction: Pleistocene of the Island of Hvar (Eastern Adriatic, Croatia).- In: HOYANAGI, K., TAKANO, O. \& KANO, K. (eds.): From the Highest to the Deepest: Abstracts, Volume A, 218, ISC 2006, Fukuoka.

PAVELIĆ, D., KOVAČIĆ, M., VLAHOVIĆ, I. \& WACHA, L. (2011): Pleistocene calcareous aeolian-alluvial deposition in a steep relief karstic coastal belt (island of Hvar, eastern Adriatic, Croatia).- Sed. Geol., 239, 46-79. doi: 10.1016/j.sedgeo.2011.05.005

PAVELIĆ, D., KOVAČIĆ, M., VLAHOVIĆ, I., MANDIC, O., MARKOVIĆ, F. \& WACHA, L. (2014): Topography controlling the wind regime on the karstic coast: late Pleistocene coastal calcareous sands of eastern mid-Adriatic, Croatia.-Facies, 60, 843-863. doi: 10.1007/s10347-014-0411-7

PAVIČIĆ, LJ., BABIĆ, LJ., CRNJAKOVIĆ, M., \& ZUPANIČ, J. (2000): The provenance of sands on north Dalmatian beaches: between ignorance and the need for Coastal Zone Management.- Period. Biolog., 102, 349-354.

PAVIČIĆ, LJ., ZUPANIČ, J. \& BABIĆ, LJ. (2003): Changing heavy mineral associations along the Outer Dinaric Eocene flysch belt: evidence for different structures along the rising Dinarides.- In: VLAHOVIĆ, I. (ed.): 22nd IAS Meeting of Sedimentology: Abstracts book, p. 149.

PELTIER, W.R. \& FAIRBANKS, R.G. (2006): Global glacial ice volume and Last Glacial Maximum duration from an extended Barbados sea level record.- Quat. Sci., 25, 3322-3337. doi: 10.1016/j.quascirev.2006.04.010

PIGORINI, B. (1968): Sources and dispersion of recent sediments of the Adriatic Sea.Marine Geol., 6, 187-229. doi: 10.1016/0025-3227(68)90031-5

PIKELJ, K. \& JURAČIĆ, M. (2013): Eastern Adriatic coast (EAC): Geomorphology and coastal vulnerability of a karstic coast.- J. Coast. Res., 29/4, 944-957. doi: 10.2112/JCOASTRES-D-12-00136.1

PIKELJ, K. \& FURČIĆ, N. (2020): Impact of cliff erosion on marine sediment composition - indication of local coastline evolution (Vrgada Island, Croatia).- In: BONORA, L. et al. (eds.): Proceedings of the Eighth International Symposium Monitoring of Mediterranean Coastal Areas. Problems and Measurement Techniques. Livorno, Italy, 2020, 462-468.

PLATT, N.H. \& KELLER, B. (1992): Distal alluvial deposits in a foreland basin setting - the Lower Freshwater Molasse (Lower Miocene), Switzerland: sedimentology, architecture and paleosols.- Sedimentology, 39, 545-565.

POUCLET, A., HORVÁTH, E., GÁBRIS, G.Y. \& JUVIGNÉ, E. (1999): The Bag Tephra, a widespread tephrochronological marker in Middle Europe: chemical and mineralogical investigations.- Bullet. Volc., 60, 265-272. doi: 10.1007/s004450050275

RIZZINI, A. (1974): Holocene sedimentary cycle and heavy-mineral distribution, Romagna-Marche coastal plain, Italy.- Sed. Geol., 11, 17-37. doi: 10.1016/00370738(74)90003-7

SARIKAYA, M.A., STEPIŠNIK, U., ŽEBRE, M, CINER, A., YILDIRIM, C., VLAHOVIĆ, I., TOMLJENOVIĆ, B., MATOŠ, B. \& WILCKEN, K.M. (2020): Last glacial maximum deglaciation of the Southern Velebit Mt. (Croatia): insights from cosmogenic 36Cl dating of Rujanska Kosa.- Med. Geosci. Rev., 2, 53-64. doi: 10.1007/s42990-020-00030-9

STRAND, K., PASSCHIER, S. \& NÄSI, J. (2003): Implications of quartz grain microtextures for onset of Eocene/Oligocene glaciation in Prydz Bay, ODP Site 1166, Antarctica.- Palaeogeogr. Palaeoclim. Palaeoec., 198, 101-111. doi: 10.1016/ S0031-0182(03)00396-1

STRAND, K. \& IMMONEN, N. (2010): Dynamics of the Barents-Kara ice sheet as revealed by quartz sand grain microtextures of the Late Pleistocene Arctic Ocean sediments.-Quat. Sci. Rev., 29, 3583-3589. doi: 10.1016/j.quascirev.2010.09.017

SURIĆ, M., JURAČIĆ, M., HORVATINČIĆ, N. \& KRAJCAR BRONIĆ, I. (2005): Late Pleistocene - Holocene sea-level rise and the pattern of coastal karst inundation records from submerged speleothems along the Eastern Adriatic Coast (Croatia).Marine Geol., 214, 1/3, 163-175. doi:10.1016/j.margeo.2004.10.030

VLAHOVIĆ, I., TIŠLJAR, J., VELIĆ, I. \& MATIČEC, D. (2002): The karst Dinarides are composed of relics of a single Mesozoic platform: facts and consequences.Geol. Croat., 55/2, 171-183.

VLAHOVIĆ, I., TIŠLJAR, J., VELIĆ, I. \& MATIČEC, D. (2005): Evolution of the Adriatic carbonate platform: palaeogeography, main events and depositional dynamics.- Palaeogeogr. Palaeoclim. Palaeoec., 220/3-4, 333-360. doi: 10.1016/j.palaeo.2005.01.011

WACHA, L., MIKULČIĆ PAVLAKOVIĆ, S., NOVOTHNY, Á., CRNJAKOVIĆ, M. \& FRECHEN, M. (2011a): Luminescence dating of Upper Pleistocene loess from the Island of Susak in Croatia.- Quat. Int., 234, 50-61. doi: 10.1016/j. quaint.2009.12.017

WACHA, L., MIKULČIĆ PAVLAKOVIĆ, S., FRECHEN, M. \& CRNJAKOVIĆ, M. (2011b): The loess chronology of the Island of Susak, Croatia.- Eiszeitalter und Gegenwart e Quat. Sci. J., 60, 153-169. doi: 10.3285/eg.60.1.11

WALKER, T.R.,WAUGH, B. \& GRONE, A.J. (1978): Diagenesis in first-cycle desert alluvium of Cenozoic age, southwestern United States and northwestern Mexico.Geol. Soc. Am. Bulletin, 89, 19-32. doi: 10.1130/0016-7606(1978)89<19:DIFD$\mathrm{AO}>2.0 . \mathrm{CO} ; 2$ 